\title{
The Right of Innocent Passage of Warships Through Territorial Seas in the Light of the Kerch Strait Incident
}

\section{Vasiliy N. Gutsulyak}

Le présent article considère le passage inoffensif de navires de guerre dans la mer territoriale d'un État côtier. Le problème a été clairement énoncé dans les événements survenus à la fin de 2018 lorsque la marine russe a tiré sur trois navires de guerre ukrainiens et capturé leurs membres d'équipage au cours de leur passage de la mer Noire à la mer d'Azov par le détroit de Kertch. L'auteur présente une appréciation juridique du pilonnage et de la saisie de navires de guerre étrangers par la marine russe. Il explique également le statut juridique des navires de guerre et de leurs membres d'équipage en temps de paix et pendant les conflits armés internationaux.

\section{Introduction}

The Kerch Strait incident occurred on 25 November 2018 when the Russian Border Guard of the Federal Security Service (FSB) fired upon and captured three Ukrainian warships including two small gunboats, Berdyansk and Nicopol, and the tug-boat Yany Kapu. These ships intended to pass from the Ukrainian port of Odessa, on the Black Sea, through the Kerch Strait to the Ukrainian port of Mariupol, on the Azov Sea. The Russian Navy seized all three Ukrainian warships and arrested twenty-four crew members, three of whom were wounded during the shelling. The next day, the FSB issued an official statement which declared that "the territorial waters of the Russian Federation, which were invaded by Ukrainian warships, were such even before the accession of Crimea to Russia."

1 [Russian] Official web-site of FSB of Russia. http://www.fsb.ru/fsb/press/message/single. htm\%21id\%3D10438316\%40fsbMessage.html accessed 11 January 2019.

The Northern Mariner / Le marin du nord, XXIX, No. 1 (Spring 2019), 25-44 
The official statement used the outdated term "the territorial waters." Both the 1982 UN Convention on the Law of the Sea (UNCLOS-82), ${ }^{2}$ to which Russia is a party, and the 1998 Russian Federal Law "On inland sea waters, territorial sea and adjacent zone of the Russian Federation" use the concept of "territorial sea." The statement said the issue was not the violation of the boundary of Russia as established by the 1993 Law of the Russian Federation, "On State boundary of the Russian Federation," "but rather about an "invasion." The legal usage of this latter term is not clear. These two errors were eliminated in the subsequent FSB statement referring to "provocative actions of the Ukrainian Navy ships." ${ }^{5}$ This new statement raises a number of questions.

The statement specified that from 0720 onward the Russian warships Don and Izumrud were taking measures to prevent the passage of the Ukrainian warships through the Kerch Strait, calling upon them by VHF and demanding them to leave the territorial sea of the Russian Federation immediately, as mandated by Article 30 of UNCLOS-82. These requirements were ignored by the Ukrainian warships. From 1830 onward, the group of ships in the Ukrainian Navy tried to escape from the Russian territorial sea on a course of $200^{\circ}$. That heading did not lead in the direction of the Kerch Strait, but in the opposite direction, namely towards the Black Sea. Thus, the requirement to leave the territorial sea immediately was fulfilled by foreign warships. Nonetheless, the Russian warships actively began to discourage this intention and, most incredibly, opened fire with the result that one of the warships was damaged and three crew members were wounded. All three Ukranian warships and their crews were captured.

This incident raised several issues. Have foreign warships the right of innocent passage? Does the passage cease to be innocent in some cases? Under international law, what should a coastal state do against a warship violating the rules of innocent passage? Can a coastal state use force against a foreign warship? These and other related issues need careful legal analysis.

\section{The concept of innocent passage}

In contrast to land territory, inland waters and inland sea waters, to which the sovereignty of the coastal state extends in full without any exceptions, the legal regime of the territorial sea is characterized by one very important feature: the

\footnotetext{
2 http://www.un.org/Depts/los/convention_agreements/texts/unclos/unclos_e.pdf accessed 11January 2019.

3 [Russian] Official Internet portal for law information. State law information system. http:// pravo.gov.ru/proxy/ips/?docbody $=\&$ nd $=102054703$

4 [Russian] Official Internet portal for law information. State law information system. http:// pravo.gov.ru/proxy/ips/?docbody $=\&$ nd $=102022486$

5 [Russian] Official web-site of FSB of Russia. http://www.fsb.ru/fsb/press/message/single. htm\%21id\%3D10438315\%40fsbMessage.html accessed 11 January 2019.
} 
right of innocent passage. ${ }^{6}$ This means that foreign ships may, in accordance with international law and without any special authorization, pass through the territorial sea of a coastal state, subject to certain conditions.

Hugo Grotius, the seventeenth century Dutch jurist who pioneered international law, considered the right of innocent passage to be related to the "most specific and unimpeachable axiom of the Law of Nations."7 Modern legal scholars, include David Froman of California who remarked that, "the right of innocent passage deserves study from both historical and contemporary perspectives because of its fundamental importance as the residual legal regime for securing transit of ships through sovereign seas." ${ }^{8}$ Phillip Jessup, a member of the Internaitonal Court of Justice in the 1960s, regarded innocent passage as a general principle and believed that "the right of innocent passage requires no supporting argument or citation of authority; it is firmly established in international law." The legal nature of innocent passage acknowledges that coastal states have voluntarily agreed to limit their sovereignty in favour of international shipping, allowing foreign vessels to pass through their territorial seas, provided that they follow the established rules. Conclusively, Bardin wrote, "the principal limitation on this sovereignty is the right of innocent passage of foreign vessels, whether private or military." 10

Thus, although coastal states have sovereignty over their territorial seas, it is limited. Article 19 of UNCLOS-82 regulates the right of innocent passage by foreign ships. According to Article 17, ships of all states, whether coastal or landlocked, enjoy the right of innocent passage through the territorial sea. Although the sovereignty of coastal states extends to the territorial seas, UNCLOS-82, Article

6 See also:[Russian] K.A. Bekyashev, International Public Law, (Moscow:, Prospect, 2004), 603 - 608; V.N. Gutsulyak, International Maritime law (public and private), (Moscow: Granitsa, 2017), 104-110; A.L. Kolodkin, International Legal Regime of the Territorial Waters of the World Ocean, (Moscow: International Relations, 1973), 151-185; G.I Tunkin, International Law, (Moscow: International Relations, 1982), 417-21; V. N. Gutsulyak, "International law of the Sea," in E. T. Usenko, G. G. Shinkaretskaya, (eds.), International Law , (Moscow: Lawyer, 2003), 305-336; S. A. Malinin, "The Right of Innocent Passage of Foreign Ships Through the Territorial Sea in 1982 Convention," in Legal issues of carriage of goods by sea and Maritime safety, ( Moscow: International Relations, 1984), 43 - 48; S. V. Molodtsov, International Law of the Sea, (Moscow: International Relations, 1987), 67- 68. [English] R.R, Churchill and A.V.Lowe. The Law of the Sea, (Manchester: Manchester University Press, 1983), 53-80; Shekhar Ghosh, "The Legal Regime of Innocent Passage through the Territorial Sea," in Hugo Caminos (ed.) Law of the Sea (London: Routledge, 2001), 3766; R.D. Neubauer, "The Right of Innocent Passage for Warships in the Territorial Sea: a Response to the Soviet Union," International Law Studies 68 (1995), 189-196.

7 Hugo Grotius, Mare Liberum (Indianapois: Oxford University Press, American Branch,1916), 7.

8 D. Froman. "Uncharted Waters: Non-innocent Passage of Warships in the Territorial Sea," San Diego Law Review 21 (1984), 625.

9 P.C.Jessup. The Law of Territorial Waters and Maritime Jurisdiction, (New York: G.A. Jennings Co., Inc., 1927), 120.

10 Anne Bardin, "Coastal State's Jurisdiction over Foreign Vessels," Pace International Law Review 14:1 (Spring 2002), 7. 
17 includes some restrictions that do not exist for the land-locked states. In the territorial sea, all foreign ships enjoy the right of innocent passage, one of the oldest and most basic legal principles governing the sea, as codified in UNCLOS-82.

In general, a passage is defined as navigation through a territorial sea for the purpose of either (a) crossing that sea without entering the inland waters or remaining in a roadstead or port facility outside the inland waters, or (b) entering or leaving the inland waters or staying on such a road or port facility. It is obvious that in this situation, the purpose of the Ukrainian warships was to enter Ukrainian inland waters, namely the Kerch Strait and the Sea of Azov. In this regard, it is necessary to determine whether the waters of the Kerch Strait and the Sea of Azov constitute the inland waters of Ukraine.

A bilateral treaty regulates the legal status of the Azov Sea and the Kerch Strait making it a special case in international law. Article 1 of the 2003 Agreement between the Russian Federation and Ukraine in states "On cooperation in the use of the Azov Sea and the Kerch Strait" the Azov Sea and the Kerch Strait are historic inland waters of both the Russian Federation and Ukraine. ${ }^{11}$ Accordingly, the Ukrainian warships had proper legal grounds to exercise the right of innocent passage, crossing the territorial sea of the coastal state to enter their inland waters.

Moreover, according to Article 2 (1) of the 2003 Agreement, merchant vessels and warships, as well as other state-owned vessels under the flag of the Russian Federation or Ukraine, operating for non-commercial purposes, enjoy freedom of navigation in the Azov Sea and the Kerch Strait. In conclusion, Russia appears to have violated the 2003 agreement by prohibiting the passage of the Ukrainian warships.

Both the 1958 Geneva Convention, "On the territorial sea and the contiguous zone" 12 and UNCLOS-82 contain the formula allowing that passage shall be continuous and expeditious. Stopping and anchoring may also be included in those rights, only if such actions are incidental to ordinary navigation, are rendered necessary by force majeure or distress, or are necessary to render assistance to persons, ships or aircraft in danger or distress.

The most essential condition for the passage of a vessel through the territorial sea of a coastal state is its qualification as innocent. As stated in the 1958 Geneva Convention and UNCLOS-82, passage is innocent so long as it is not prejudicial to the peace, good order or security of the coastal State. Such passage shall take place in conformity with the provisions of the above Conventions and with other rules of international law.

The 1958 Geneva Convention, however, fails to establish the meaning of the concept of "peace, good order or security of a coastal state." These can be interpreted quite broadly. This uncertainty was eliminated by UNCLOS-82,

11 [Russian] The Bulletin of International Treaties, (Moscow: "Legal Literature" of the Presidential Administration of the Russian Federation, 2004), No. 7, 46 - 47.

12 https://www.gc.noaa.gov/documents/8 11958 territorial sea.pdf accessed 12 January 2019. 
which, in part 2 of Article 19, specified that the passage of a foreign ship shall be considered prejudicial to the peace, good order or security of the coastal state if, in the territorial sea it engages in any of the following twelve activities:

(a) any threat or use of force against the sovereignty, territorial integrity or political independence of the coastal State, or in any other manner violates the principles of international law embodied in the Charter of the United Nations;

(b) any exercise or practice with weapons of any kind;

(c) any act aimed at collecting information which prejudices the defense or security of the coastal State;

(d) any act of propaganda aimed at affecting the defense or security of the coastal State;

(e) the launching, landing or taking on board of any aircraft;

(f) the launching, landing or taking on board of any military device;

(g) the loading or unloading of any commodity, currency or person contrary to the customs, fiscal, immigration or sanitary laws and regulations of the coastal State;

(h) any act of willful and serious pollution contrary to this convention;

(i) any fishing activities;

(j) the carrying out of research or survey activities;

(k) any act aimed at interfering with any systems of communication or any other facilities or installations of the coastal State;

(l) any other activity not having a direct bearing on passage.

The above list is not exhaustive as such activities may include any other activity that is not actually relevant to the passage. However, it should be noted, that any activity not directly related to the passage does not automatically make the passage innocent.

In this regard, it is interesting to note that, according to A. Bardin, "a study of UNCLOS Article 19 (2) leads to the conclusion that most of the activities listed as incompatible with innocent passage are activities that are characteristic of warships." ${ }^{\prime 3}$ Article 20 of UNCLOS-82 mandates that a submarine navigate on the surface and show its flag for its passage to be deemed innocent.

The coastal state may take the necessary steps to prevent a passage through its territorial sea that is not innocent. It can, without discrimination among foreign vessels, temporarily suspend the innocent passage of foreign ships in specific areas of its territorial sea, if it is essential to the protection of its security. The coastal state may also adopt laws and regulations relating to innocent passage through the territorial sea.

Therefore, according to Article 21 of UNCLOS-82, a coastal state may adopt

13 Bardin, supra note 10,38 . 
laws and regulations, in conformity with the provisions of this convention and other rules of international law, relating to innocent passage through the territorial sea, in respect to all or any of the following:

(a) the safety of navigation and the regulation of maritime traffic;

(b) the protection of navigational aids and facilities and other facilities or installations;

(c) the protection of cables and pipelines;

(d) the conservation of the living resources of the sea;

(e) the prevention of infringement of the fisheries laws and regulations of the coastal state;

(f) the preservation of the environment of the coastal state and the prevention, reduction and control of pollution thereof;

(g) marine scientific research and hydrographic surveys;

(h) the prevention of infringement of the customs, fiscal, immigration or sanitary laws and regulations of the coastal state.

Such laws and regulations shall not apply to the design, construction, manning or equipment of foreign ships unless they impact generally accepted international rules or standards. In addition, the coastal state is under an obligation to give due publicity to all such laws and regulations.

Finally, every foreign ship exercising the right of innocent passage through the territorial sea must comply with all such laws and regulations and all generally accepted international rules concerning the prevention of collisions at sea. This includes, first and foremost, the Convention on the International Regulations for Preventing Collisions at Sea, 1972 (COLREGs-72) which are published by the International Maritime Organization. As of 1 January 2019, participants in the COLREGs-72 include 157 states whose gross tonnage is 99.16 per cent of the world. Rule 1 of COLREGs-72 states that the rules apply to all vessels upon the high seas and all waters connected to the high seas and navigable by seagoing vessels. Thus, COLREGs-72 applies to the territorial seas of the overwhelming majority of coastal states. The Russian Federation and Ukraine are participants of COLREGs-72.

Where necessary in regard to the safety of navigation, foreign ships may be required to exercise the right of innocent passage through the state's territorial sea utilizing sea lanes and traffic separation schemes. The coastal state shall clearly indicate such sea lanes and traffic separation schemes on charts to which due publicity shall be given. The coastal state imposes special requirements for innocent passage through the territorial sea on foreign nuclear-powered ships and ships carrying nuclear or other inherently dangerous or noxious substances (Article 23 of UNCLOS-82). When exercising the right of innocent passage through the territorial sea, such vessels shall carry documents and observe special precautionary measures established by international agreements. According to 
Article 26 of UNCLOS-82, no charge may be levied upon foreign ships solely for their passage through the territorial sea. But charges may be levied upon a foreign ship as payment for specific services rendered.

\section{Innocent passage and warships}

In the Corfu Channel case the International Court of Justice recognized that all foreign vessels, (whether warships or merchant ships), have a right of innocent passage.${ }^{14}$ This case was brought before the court on 22 May 1947, in an application filed by the Government of the United Kingdom instituting proceedings against the Government of Albania. An incident had occurred in the Corfu Channel on 15 May 1946. Two British cruisers, while passing through the Corfu Channel, were fired upon by an Albanian coastal battery. Britain had protested, stating that innocent passage through straits is a right recognized by international law. Albania replied that foreign warships and merchant vessels had no right to pass through Albanian territorial waters without prior authorization.

On 22 October 1946 two British destroyers struck mines while passing through the Corfu Channel and suffered serious damage, including loss of life. In November 1947, the United Kingdom conducted mine clearance operations in Corfu Channel without the authorization of Albania. The court found that the British vessels were exercising the right of innocent passage in the Albanian territorial waters but condemned the UK for having swept the mines without Albania's permission.

The Japanese scholar Tanaka noted that "the Japanese government takes the view that the passage of foreign warships carrying nuclear weapons through its territorial sea is not innocent, whilst Japan generally admits the right of innocent passage of foreign warships." 15

In accordance with Article 29 of UNCLOS-82, "warship" refers to a ship belonging to the armed forces of a state bearing the external marks distinguishing its nationality, under the command of an officer duly commissioned by the government of the state and whose name appears in the appropriate service list or its equivalent. It must be manned by a crew under regular armed forces discipline. If a warship is required to comply with regulations and fails to act as directed, the coastal state may order her to leave its territorial sea immediately according to Article 30 of UNCLOS-82. The main purpose of this is that the requirement to leave the territorial sea is the only possible measure that a coastal state may apply to a foreign warship violating the rules of innocent passage. The flag state will be responsible for its warships if the coastal state suffers any loss or damage caused

14 https://www.icj-cij.org/files/case-related/1/001-19490409-JUD-01-00-EN.pdf accessed 14 February 2019.

15 Yoshufumi Tanaka. The International Law of the Sea, (Cambridge: Cambridge University Press, 2012), 87. 
by such vessels as a result of non-compliance with the local laws and regulations pursuant to Article 31 of UNCLOS-82.

The Russian legislation regarding the innocent passage of warships contains similar provisions. Accordingly, the status of the Russian territorial sea is defined in the 1998 Federal Law "On inland sea waters, territorial sea and contiguous zone of the Russian Federation." The sovereignty of the Russian Federation extends to the territorial sea, the airspace above it, as well as to the bed of the territorial sea and its subsoil, recognizing the right of innocent passage of foreign vessels through the territorial sea (Article 2, part 4).

The articles of the 1998 law relating to innocent passage through the territorial sea of Russia reproduce the provisions of UNCLOS-82 almost verbatim. Article 12 (1) of the law prescribes that foreign warships and other state-owned vessels enjoy the right of innocent passage through the territorial sea in accordance with this federal law and with generally recognized principles and norms of international law and international agreements of the Russian Federation.

Provisions concerning the innocent passage of warships are reflected in a number of Russian regulations. According to Article 20 of Rules of Navigation and Stay of the Foreign Warships and Other Government Ships Operated for Non-commercial Purposes in the Territorial Sea, in Inland Sea Waters, on Naval Bases, in Points of Basing of the Warships and Seaports of the Russian Federation approved by the Order of the Government of the Russian Federation on 2 October 1999, N 1102 (1999 Rules), ${ }^{16}$ if the warship does not observe the legislation of the Russian Federation concerning passage through the territorial sea and ignores any requirement concerning observance of the legislation of the Russian Federation addressed to her, officials of the specially authorized Federal Executive Authorities of Border Guard, of Defence, of Internal Affairs and of Environmental Protection may order the ship to leave the territorial sea immediately.

Moreover, Article 21 of the 1999 Rules states that, in peacetime, all disputes between officials of the Federal Executive Authorities and the ship's commander shall be resolved exclusively by diplomatic means.

\section{The immunities of warships}

Thus, warships on a par with the merchant ships enjoy innocent passage through the territorial sea of the coastal state. ${ }^{17}$ However, unlike a merchant ship, in accordance with Article 32 of UNCLOS-82, nothing affects the immunities of warships and other government ships operated for non-commercial purposes. The authorities of the coastal state are very limited in taking any forceful measures against a warship that violates the laws and regulations of the said coastal state.

16 [Russian] Collection of the legislation of the Russian Federation, 18.10.1999, N 42, Art. 5030.

17 See e.g.[Russian] G.G. Ivanov, The Law Regulating Maritime Shipping in the Russian Federation, (Moscow: Spark, 2002), 216. 
The USS Pueblo incident illustrates very clearly the status of a warship. ${ }^{18}$ On 23 January 1968 Pueblo was captured by North Korea. The United States claimed the vessel was on the high seas, but North Korea insisted she was in its territorial waters. Furthermore, the US stated that the seizure of foreign warships or other attacks against them are much too dangerous and provocative to be permitted by international law. This restriction on the use of force by a coastal state is set forth in Article 23 of the 1958 Convention on the territorial sea, which authorizes, as the coastal state's sole remedy, to be ordering said warship to leave the territorial sea. ${ }^{19}$ Senator Richard B. Russell, chairman of the Senate Armed Services Committee, assessed the Pueblo capture as "amounting to an act of war." Secretary of State Dean Rusk agreed, saying that the seizure was, "in the category of actions to be considered as an act of war." 20

Warship immunity was confirmed by the International Tribunal for the Law of the Sea in the ARA Libertad (Argentina vs Ghana) case on 15 December 2012. ${ }^{21}$ On 14 November 2012 Argentina filed with the Tribunal a request for the prescription of provisional measures under Article 290, paragraph 5, of UNCLOS-82 in a dispute concerning the detention by Ghana of the Argentine navy's sail training ship, ARA Libertad. Argentina requested that the Tribunal declare that the Republic of Ghana, by detaining the Libertad and keeping it detained, not allowing it to refuel and adopting several judicial measures against it violated the international obligation respecting the immunities from jurisdiction and execution enjoyed by such vessels, pursuant to Article 32 of UNCLOS-82 and Article 3 of the 1926 Convention for the Unification of Certain Rules concerning the Immunity of State-owned Vessels as well as pursuant to well-established general or customary international law rules in this regard. Second, it prevented the exercise of the right to sail out of the waters subject to the jurisdiction of the coastal state and the right of freedom of navigation enjoyed by the said vessel and its crew, pursuant to Articles 18, paragraph 1(b), 87, paragraph 1(a), and 90 of UNCLOS-82. The Tribunal, pending a decision, unanimously prescribed the following provisional measures: Ghana was forthwith and unconditionally to release the Libertad and shall ensure that the Libertad, its commander and crew are able to leave the port of Tema and the maritime areas under the jurisdiction of Ghana. In addition, it shall ensure that the Libertad is resupplied to that end.

Thus, the immunity of a warship is confirmed by the provisions of international

18 https://www.cia.gov/library/center-for-the-study-of-intelligence/csi-publications/csi-studies/ studies/vol-59-no-1/pdfs/Revisiting-Pueblo-and-EC121.pdf ; the Pueblo, EC-121, and Mayaguez incidents: some continuities and changes. Robert R. Simmons https://core.ac.uk/download/ pdf/56353786.pdf accessed 10 February 2019.

19 Telegram from the Department of State to the Embassy in Korea on $3^{\text {rd }}$ February 1968 https:// history.state.gov/historicaldocuments/frus1964-68v29p1/d262 accessed 15 October 2019.

20 New York Times, 24 and 25 January 1968; Washington Post, 25 January 1968.

21 https://www.itlos.org/fileadmin/itlos/documents/cases/case no.20/published/C20 Order 151212.pdf accessed 10 February 2019. 
conventions, doctrine and practice.

\section{The criminal jurisdiction over warship crew members}

Another issue that needs to be investigated in connection with the Kerch incident is the coastal state's criminal jurisdiction over the warship's crew. No doubt, a coastal state has criminal jurisdiction over merchant vessels exercising the right of innocent passage, as well as over persons on board such vessels.

However, a coastal state may exercise criminal jurisdiction over foreign ships in its territorial sea only according to Article 27 of UNCLOS-82 stating the following:

1. The criminal jurisdiction of the coastal State should not be exercised on board a foreign ship passing through the territorial sea to arrest any person or to conduct any investigation in connection with any crime committed on board the ship during its passage, save only in the following cases:

(a) if the consequences of the crime extend to the coastal State;

(b) if the crime is of a kind to disturb the peace of the country or the good order of the territorial sea;

(c) if the assistance of the local authorities has been requested by the master of the ship or by a diplomatic agent or consular officer of the flag State; or

(d) if such measures are necessary for the suppression of illicit traffic in narcotic drugs or psychotropic substances.

But these provisions do not affect the right of the coastal state to take any steps authorized by its laws for the purpose of an arrest or investigation on board a foreign ship passing through the territorial sea after leaving inland waters. In the cases provided above, the coastal state shall, if the master so requests, notify a diplomatic agent or consular officer of the flag state before taking any steps and shall facilitate contact between such agent or officer and the ship's crew. In cases of emergency this notification may be communicated while the measures are being taken.

In considering whether or in what manner an arrest should be made, the local authorities shall have due regard for the interests of navigation. As a rule, except under some circumstances, the coastal state may not take any steps on board a foreign ship passing through the territorial sea to arrest any person or to conduct any investigation in connection with any crime committed before the ship entered the territorial sea. The exception applies only to the ship, proceeding from a foreign port and passing through the territorial sea without entering inland waters.

However, unlike the laws regarding merchant shipping, the status of the warship crew members has some peculiarity. Professor S. Gureev believes that, "when the warship crew members are on the shore in uniform and in the performance of their duties, they are immune from the criminal jurisdiction of the coastal state." ${ }^{22}$ Since

22 [Russian] S. A. Gureev. International Maritime Law Textbook, (Moscow: "Legal Literature," 
only diplomatic representatives could be immune from criminal prosecution, that could not be accepted. If a foreign warship crew member has committed a crime in the territory of a coastal state, the coastal state authorities can detain and arrest every warship crew member who has committed a crime. In addition, they can exercise criminal jurisdiction without any exceptions.

Regarding another matter, the coastal state may extradite the offender to the flag state authorities, for example, according to bilateral agreements on mutual extradition. If the seaman, after committing the crime, managed to return onboard the warship, the authorities are already limited because the warship has immunity and extraterritoriality. In this regard, boarding a warship is possible only with the permission of the commander. The only action that the coastal state authorities can exercise in that situation is to require the extradition of the offender. In case of refusal, coastal state authorities may demand that the warship leave the territory immediately, due to the ship's violation of the state's legislation.

On 11 September 2001 during the stay of the Italian warship Vittorio Veneto in the Russian port of Novorossiysk, crew member Giuseppe Pillero, while on shore leave, murdered a Russian teenager. The murderer took refuge on board the ship, and Commander Franco Fabre categorically refused to let representatives of the Prosecutor's office board to arrest him, since the ship can be regarded as the territory of the Italian State. Thus, the Italian military did not allow Russian law enforcement agencies to exercise criminal jurisdiction. The ship left the port of Novorossiysk. Nevertheless, after six years of trials, the Court of the Italian city of Taranto sentenced the murderer to fourteen years in prison for the killing. The Italian Ministry of Defence was obliged to pay the mother of the deceased compensation of more than $€ 100,000$. $^{23}$

In summary, a warship's crew members in the territory of a foreign state, do not have immunity from criminal jurisdiction. However, on board a warship, the decision to exercise the jurisdiction is taken by the commander of the warship. The boarding of a foreign warship without the commander's permission is in contravention of international law.

The situation fundamentally changes if we are talking about a seizure of warship crew members during an international armed conflict. Can the use of weapons by naval forces against foreign warships in the coastal state's waters be considered as an international armed conflict? If the answer to this question is "yes," this leads to a very important conclusion that the Ukrainian warship members captured by the Russian Navy fall under the protection of International Humanitarian Law, namely the 1949 Geneva Conventions with the 1977 Additional Protocols. ${ }^{24}$

In whole, the question of when, in peacetime, the norms of International Humanitarian Law become applicable, is complicated enough. Article 2, common

2003), 57

23 https://www.svoboda.org/a/396622.html accessed 12 February 2019.

24 http://www.un.org/en/genocideprevention/documents/atrocity-crimes/Doc.34 AP-I-EN.pdf accessed 12 February 2019. 
to the 1949 Geneva Conventions, states that in addition to the provisions which shall be implemented in peacetime, the provisions of the Conventions shall apply to "all cases of declared war or of any other armed conflict which may arise between two or more of the High Contracting Parties, even if the state of war is not recognized by one of them." Both the Russian Federation and Ukraine are participants of the 1949 Geneva Conventions. ${ }^{25}$ Although Article 2 cannot clearly define the essence of an armed conflict, it is important to mention that an international armed conflict can take place even if it is not recognized by one of the parties.

International Humanitarian Law distinguishes two types of armed conflicts, namely international armed conflicts, opposing two or more States, and noninternational armed conflicts. The Commentary on the 1949 Geneva Conventions confirms that "any difference arising between two States and leading to the intervention of armed forces is an armed conflict within the meaning of Article 2 , even if one of the Parties denies the existence of a state of war. It makes no difference how long the conflict lasts, or how much slaughter takes place." ${ }^{26} \mathrm{D}$. Schindler states that, "the existence of an armed conflict within the meaning of Article 2 common to the Geneva Conventions can always be assumed when parts of the armed forces of two States clash with each other." ${ }^{27}$ Moreover, he believes that, "any kind of use of arms between two States brings the Conventions into effect." 28

According to the International Committee of the Red Cross (ICRC) Opinion Paper (March 2008), international armed conflict occurs "when one or more States have recourse to armed force against another State, regardless of the reasons or the intensity of this confrontation" 29 and it "exists whenever there is resort to armed force between two or more States." ${ }^{30}$ The paper also contains one more very essential provision. It declares that "relevant rules of International Humanitarian Law may be applicable even in the absence of open hostilities." ${ }^{1}$

Finally, another significant provision of the paper reads as follows: "Moreover, no formal declaration of war or recognition of the situation is required. The existence of an international armed conflict and as a consequence, the possibility to apply International Humanitarian Law to this situation, depends on what actually happens on the ground. It is based on factual conditions." ${ }^{32}$

25 Russia ( USSR) signed on 12 December 1949 and ratified 10 May 1954, and the Ukraine 12 December 1949 and 03August 1954.

26 D. Schindler, "The Different Types of Armed Conflicts According to the Geneva Conventions and Protocols" Recueil des Cours de l'Academie de Droit International (The Hague: Brill, 1979) 163: 131.

27 Ibid.

28 Ibid.

29 https://www.icrc.org/en/doc/assets/files/other/opinion-paper-armed-conflict.pdf , 1, accessed on 10 February 2019.

30 Ibid.

31 Ibid.

32 Ibid. 
The International Criminal Tribunal for the former Yugoslavia confirmed a general definition of international armed conflict. In the Tadic case, the Tribunal stated that "an armed conflict exists whenever there is a resort to armed force between States." 33 The San Remo Manual on International Law applicable to Armed Conflicts at Sea, 12 June 1994, states that "parties to an armed conflict at sea are bound by the principles and rules of International Humanitarian Law from the moment armed force is used." 34

In sum, we can conclude that the Kerch incident had all the signs of an armed conflict, and therefore the captured crew members of Ukrainian warships (the EU calls them "servicemen" ${ }^{35}$ ) are prisoners of war in accordance with Article 4 of the 1949 Geneva Convention Relative to the Treatment of Prisoners of War, and they can take advantage of such status. When questioned on the subject, every crew member of a warship detained during international armed conflict is bound to give only his surname, first names and rank, date of birth, and army, regimental, personal or serial number. Failing this, a crew member may provide only equivalent information, under Article 17 of the Geneva Convention Relative to the Treatment of Prisoners of War of 12 August 1949.

No doubt, immunities will protect warships in regard to seizure and arrest of the vessel and crew members on board. The only thing that the authorities of the coastal State can do in this situation, as already mentioned above, is to require the warship to immediately leave the territorial sea.

\section{The Black Sea incident, 1988}

An example of the exercise of the right of innocent passage by warships took place in 1988 off the coast of the Crimean Peninsula (former USSR). ${ }^{36}$ According to Lieutenant Commander John W. Rolph, "the importance of specifically defining the concept was never illustrated more graphically than it was during the Black Sea bumping incident of 1988." 37

On 12 February 1988 two US warships, the missile cruiser Yorktown and

33 International Criminal Tribunal for the former Yugoslavia, The Prosecutor v. Dusko Tadic, Decision on the Defence Motion for Interlocutory Appeal on Jurisdiction, IT-94-1-A, 2 October 1995, para. 70 .

34 https://ihl-databases.icrc.org/ihl/INTRO/560?OpenDocument accessed 7 February 2019.

35 http://assembly.coe.int/nw/xml/XRef/Xref-XML2HTML-EN.asp?fileid=25419\&lang=en para.2, 8.6, accessed 11 February 2019.

36 See also [Russian] V.N.Gutsulyak. "The contemporary law regime of the territorial sea of the Russia," State and Law: Journal of the Russian Academy of Sciences 8 (2018), 86-93; V.N.Gutsulyak. "International Law of the Sea" in R.M.Valeev and G.I.Kurdyukov (eds.) International Law, (Moscow:Statut, 2010), 409-27; P. D.Barabolya. "On the question of innocent passage through the territorial sea," Soviet Yearbook of Maritime Law (Moscow: Mortekhinformreklama, 1989), 33 - 45; [English]: Lieutenant Commander John W. Rolph. "Freedom of Navigation and the Black Sea Bumping Incident: How "Innocent" Must Innocent Passage Be?", Military Law Review 135 (Winter1992), 137-167.

37 Rolph, 138. 
the destroyer Caron, entered the territorial sea of the USSR near the Crimean Peninsula, approaching the shore at a distance of six miles. The Soviet warships Bezzavetny, SKR-6 and Yamal came to the area to intercept the Americans and began a manoeuvre to approach them. The Bezzavetny caught up with Yorktown and, for some time, the ships were on parallel courses, with very little distance between them. Then Bezzavetny changed course hard-a-starboard and struck Yorktown's hull aft at an angle of about thirty degrees. Because of the impact and friction, both ships began to spark and the paint coating of both ships caught fire. Bezzavetny's anchor damaged the American cruiser's side, and made a hole in her own hull forward. Simultaneously, the $S K R-6$ began to brush up against the port side of the Caron, damaging her side, handrails and lifeboat. Thereafter, both the Caron and the Yorktown continued on their course and completed their passage through Soviet waters. No more incidents took place, but the American warships remained under escort of Soviet vessels until they re-entered the high seas.

Both the USSR and USA exchanged a series of diplomatic protests over the Black Sea incident. The position of the Soviet Union on this incident stated that in accordance with the 1982 Law of the USSR "On the State Boundary of the USSR" and other by-laws, was that the foreign warships had violated restrictions which sacrificed their right to enjoy innocent passage. To the leadership of the Soviet Navy, the pushing and bumping of a foreign warship that violated the laws of a coastal state and refused to leave the territorial sea, although they may be considered exceptional measures, were the only effective means of stopping the violation and a reasonable alternative to the use of lethal weapons. The Americans considered it a violation of the freedom of navigation under UNCLOS-82, and decided "to manifest a non-provocative exercise on the right of innocent passage." They argued that the transits of the Caron and the Yorktown represented valid exercises of the right of innocent passage.

Thereafter, on 23 September 1989, the United States and the former Soviet Union signed the Joint Statement on the Uniform Interpretation of Rules of International Law Governing Innocent Passage. Article 2 stated, "All ships, including warships, regardless of cargo, armament or means of propulsion, enjoy the right of innocent passage through the territorial sea in accordance with international law, for which neither prior notification nor authorization is required." 38 The document also contains an important provision concerning warships that violate the right of innocent passage. If a warship engages in conduct which violates such laws or regulations or renders its passage not innocent and fails to take corrective action upon request, the coastal state may require it to leave the territorial sea, as set forth in Article 30 of the Convention of 1982. In such case, the warship shall do so immediately. ${ }^{39}$ Further, the parties agreed that all differences which may arise

38 https://cil.nus.edu.sg/wp-content/uploads/formidable/18/1989-USA-USSR-Joint-Statementwith-Attached-Uniform-Interpretation-of-Rues-of-International-Law-Governing-Innocent-Passage. pdf. accessed 14 February 2019.

39 Ibid. 


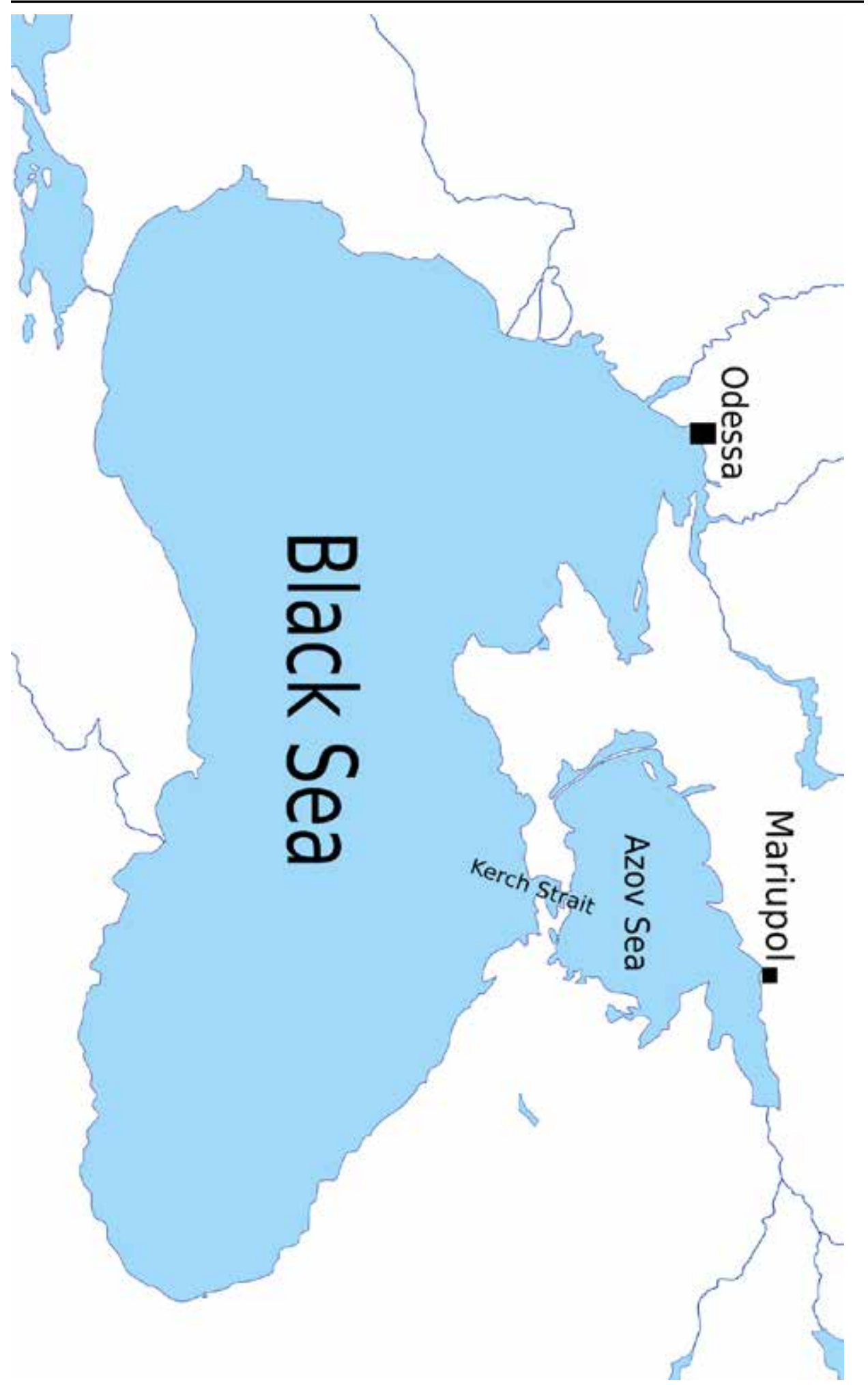


regarding a particular case of passage of ships through the territorial sea shall be settled through diplomatic channels or other agreed-upon means.

In general, the Soviet doctrine of the International Law strictly adhered to the provisions on the inadmissibility of the use of weapons against foreign warships in peacetime. Professor Meshera believed in this regard that "such measures as detention of a foreign warship is unacceptable whatever the motivating reasons." ${ }^{40}$ According to the Soviet Dictionary of the International Law of the Sea, "all warships have immunity from foreign jurisdiction, the basis of which is the sovereign equality of all States. The immunity of a warship means nonproliferation of the laws of any state other than the flag state, non-jurisdiction of foreign authorities, freedom from coercive actions such as detention, arrest, search, confiscation, requisition, etc." ${ }^{41}$

\section{The procedure governing the use of weapons in accordance with Russian legislation}

According to the 1993 Law "On the State boundary of the Russian Federation," the Border Authorities and Armed Forces of the Russian Federation, providing the protection of the state boundary may use weapons to repel armed invasion and to prevent attempts to hijack vessels without passengers. Weapons may also be used in response to the use of force or when the cessation of the violation or the arrest cannot be conducted by other means; to protect citizens from an attack that threatens their life and health; to release hostages; to repel attacks on the military personnel performing official duties; to rescue members of their families when their lives are in immediate danger; and to repel attacks on the armed forces of the Russian Federation, other troops, military units and bodies involved in the protection of the State boundary.

The procedure governing the use of weapons is regulated in more detail by the Rules of Use of the Weapon and War Equipment for the Protection of the Boundary, the Exclusive Economic Zone and the Continental Shelf of the Russian Federation approved by the Order of the Government of the Russian Federation N 80, dated 24 February 2010 (2010 Rules). ${ }^{42}$ According to Article 4 of these rules, weapons and war equipment may be used in cases and in accordance with the requirements provided by the Russian legislation and international law. But the 2010 Rules do not contain any measures, which can be taken against foreign warships.

In conclusion, the 1993 Law and 2010 Rules don't provide for the use of weapons against foreign warships, but only against merchant vessels, because

40 [Russian] V.F.Meshera. Soviet Law of the Sea, (Moscow: Transport, 1980), 68.

41 [Russian] Y.G. Barsegov, Dictionary of the International Law of the Sea, (Moscow: International Relations, 1985), 32.

42 [Russian] The Collection of the Legislation of the Russian Federation", No. 9, (Moscow: "Legal Literature" of the Presidential Administration of the Russian Federation, September 2010), art.970. 
warships have immunity in accordance with Article 32 of UNCLOS-82. In this regard, professor J. Kraska believes that "no nation may exercise legal competence over them [warships] and their capture or arrest is unlawful." ${ }^{43}$ This practice is confirmed by customary law, which, in particular, is reflected in the 1926 Brussels Convention on the Immunity of State-owned Ships. Under the same provisions, warships are not subject to the enforcement jurisdiction of the coastal state.

Not all scholars, however, share this point of view. For example, Churchill and Lowe believe that "warships which violate coastal laws concerning passage through the territorial sea and which ignore requests for compliance may be required to leave the territorial sea and the coastal State may use any force necessary to compel them to do so." ${ }^{44}$ This does not imply the possibility of using weapons against warships. In this regard, it is important to consider Article 301 of UNCLOS- 82 which says that in exercising their rights and duties under this convention, states parties shall refrain from any threat or use of force against the territorial integrity or political independence of any state, or in any other manner inconsistent with the principles of international law embodied in the Charter of the United Nations.

In sum, by using weapons against foreign warships in peacetime, the Russian navy violated not only the international law, but also its own Russian legislation, which only allows weapons to be used in the event of an emergency against merchant ships, not warships.

\section{Who gave the order to attack?}

The frequent allegations that the decision to use weapons was taken at almost the highest level are, in our view, untrue. The seizure of the Ukrainian warships most likely does not reflect a decision "at the highest levels" of the Russian government. The fact is that Article 24 of the 2010 Rules clearly and unambiguously establishes that the decision to use deadly force is taken by the chief of the Border Guard or the person performing his duties. The commander of the warship, according to Article 25 of the 2010 Rules, can decide to use deadly force only for its necessary defence or in conditions of extreme necessity, when the delay creates an immediate danger to the ship's life and in cases which include the use of weapons without warning.

Thus, most likely the decision was made at the level of the leadership of the Russian Border Guard, not at the highest level of authority. This conclusion is confirmed by the information posted in a number of Russian media. According to the extracts from the log-book of the Russian warship Izumrud: "at 2054 on 25 November 2018, permission has been granted from Admiral G.N. Medvedev, the chief of the Russian Border Guard, to open fire for destruction." At 2055 it

43 James Kraska. “The Kerch Strait Incident: Law of the Sea or Law of Naval Warfare?” https:// www.ejiltalk.org/the-kerch-strait-incident-law-of-the-sea-or-law-of-naval-warfare/ published on 3 December 2018, accessed 12 January 2019.

44 Churchill and Lowe, 77. 
commenced..$^{45}$

It is obvious that the persons responsible for these thoughtless actions, demonstrate both blatant ignorance of international law and of Russian legislation, as well as complete disregard for its norms. As a result of these actions, they have caused serious damage to Russia's reputation and economy.

The aftermath of the Kerch Strait incident is well known. This includes the strengthening of anti-Russian sanctions, a new spiral of tensions in international relations, and another missed opportunity to restore normal relations with the West.

On 26 November 2018, Russia and Ukraine called for an emergency meeting of the United Nations Security Council. The Russian version of the incident as a violation of Russian boundaries was supported by China, Kazakhstan and Bolivia. The Ukraine position on the Kerch Strait incident characterized as an "attack by Russia" was supported by the USA and (members EU), UK, France, Poland, Sweden and the Netherlands. Nikki Haley, US Ambassador to the UN, said that those actions were an "outrageous violation" of Ukrainian territory. ${ }^{46}$ US President Donald Trump cancelled his planned meeting with Russian President Vladimir Putin during the G-20 summit in Argentina, claiming that the sole reason for the cancellation was the situation with Ukrainian warships and its crew members.

United Nations General Assembly Resolution A/73/L.47 was adopted on 17 December 2018, in response to the Kerch Strait incident. The non-binding resolution condemned the Kerch Strait incident. In resolution 433 on 12 December 2018, the European Parliament condemned "the Russian aggression in the Kerch Strait" and demanded the release of all Ukrainian vessels and servicemen. It also called on the European Union to introduce sanctions against Russia if the servicemen were not released and if there was any further military escalation.

On 24 January 2019, the Parliamentary Assembly of the Council of Europe (PACE) adopted resolution 2259 (2019) concerning "Escalation of tension around the Azov sea and the Kerch Strait and threats to European security," which, in particular, states that "the Assembly condemns the use of military force by the Russian Federation against Ukrainian warships and their crews." ${ }^{77}$ The Assembly urges the Russian Federation to release the Ukrainian servicemen immediately and to ensure that they are granted the necessary medical, legal and/or consular assistance in accordance with relevant provisions of international humanitarian law such as the Geneva Conventions.

The Kerch Strait incident created three dangerous precedents. First, the institution

45 https://echo.msk.ru/blog/ilya_s_novikov/2352751-echo/ accessed 12 January 2019.

46 National Public Radio Inc. (US). "Russia's Seizure Of Ukrainian Ships Is An 'Outrageous Violation,"Haley Says At U.N.," 26 November 218, https://www.npr.org/2018/11/26/670746252/ ukraine-considers-martial-law-after-russia-seizes-its- ships-near-crimea?t=1543254273384 accessed 14 January 2019.

47http://assembly.coe.int/nw/xml/XRef/Xref-XML2HTML-EN.asp?fileid=25419\&lang=en accessed 14 January 2019. 
of innocent passage through the territorial sea is in fact being devalued and grossly trampled upon. If some flag states were to accept the attack by a coastal state against a warship exercising the right of innocent passage because she was suspected of any navigational rules violation, it would weaken significantly the existing right of innocent passage that has its roots far back in history.

Second, for the first time in the history of contemporary international law, a coastal state has used lethal weapons against foreign warships, which, unlike merchant ships, have inviolability. The only thing a coastal state can do in case of any violation by a warship is to require its departure from the State's territorial sea immediately.

Third, the principle of the immunity of government ownership, which is reflected in the formula "par in parem non habet imperium," was violated. The saddest thing is that the Kerch incident lays a time-bomb in international relations and could cause a "boomerang effect," referring to the adoption of similar measures to merchant ships and warships under the flag of the Russian Federation.

The following summary conclusions can be drawn from the above.

1. Warships as well as merchant and other vessels may exercise innocent passage through the territorial sea of a coastal State in compliance with the established rules. The claims of C.J. Colombos and other authors on the uncertainty of the innocent passage of warships have lost their relevance after adoption of UNCLOS$82.4^{48}$

2. Non-compliance with innocent passage rules by a foreign warship may entail the only possible measure from the coastal State, the requirement to leave the territorial sea immediately.

3. The International Law does not answer the question about what is to be done when a foreign warship refuses to leave the territorial sea despite the demands of the coastal State. It seems, there may be only one alternative: to resolve the situation exclusively by diplomatic means. The use of lethal weapons against a foreign warship is absolutely unacceptable because it violates the principle of immunity and inviolability of the warship in accordance with Article 32 of the UNCLOS-82. Moreover, de jure, such actions may mean a declaration of war. The characteristic historical example in this regard is the Tonkin Gulf incident, when on August 2, 1964, the USS Maddox was fired upon by three North Vietnamese vessels. This incident was the basis for US President Lyndon Johnson starting the Vietnam War, which lasted for almost eleven years between 1964 and April 1975.

4. The use of lethal weapons against a foreign warship that obeys the requirements of the coastal state to leave the territorial sea, as was the case in the Kerch Strait incident, is not just as a violation of international and national law, but is also

48 [Russian] C.J.Colombos. The International Law of the Sea, (Moscow: Progress, 1973), 125; Myres S. McDougal and William T. Burke, The Public Order of the Oceans. A Contemporary International Law of the Sea, (London: Yale University Press, 1962), 216-226. 
contrary to common sense.

Any such incident should not be out of sight of international law scholars, but should become a subject of a thorough legal analysis and an elaboration of the necessary measures to prevent its occurrence in the future. 